\title{
Ecotourism as a Means of Conservation of the Landscape of Rodrigues Island
}

\begin{abstract}
The Indian Ocean island of Rodrigues provides an interesting landscape case study. It offers a characteristic example of a small island territory whose natural and environmental resources have been overexploited by human activity and whose inhabitants are now clinging to the remains of its symbolic heritage in an attempt to implement conservation and sustainable reconstruction. From this perspective, rurality, with its attendant agricultural practices, its traditional gardens and its natural or humanized landscapes, has become an essential asset; one which the island is trying to promote by means of a tourist strategy based on the enhancement of economic and identity-focused parameters.

Keywords

Rodrigues $\cdot$ landscape $\cdot$ domestic gardens $\cdot$ ecotourism $\bullet$ terraces - agriculture

(c) University of Warsaw - Faculty of Geography and Regional Studies
\end{abstract}

Jean-Michel Jauze

Geographical Researches and Studies Centre

University of Reunion Island

France

e-mail: jean-michel.jauze@univ-reunion.fr

Received: 22 February 2015

Accepted: 28 May 2015

\section{Introduction}

Located in the south-east Indian Ocean, Rodrigues, the smallest of the three islands in the Mascarene archipelago (Figure 1), is a former dependency of Mauritius and has been an autonomous territory since 2002. Its situation is typical of the difficulties being faced by isolated, insular areas attempting to achieve development without outside aid (in this instance, from Mauritius, France and the European Union). Factors such as the unequal balance between exports and imports, ecological problems, water shortages, issues relating to agricultural economics, the low standard of living, and emigration of the young to Mauritius and Australia combine to paint a rather depressing portrait.

Modern visitors looking at the parched savannah that now covers a considerable area of the island may find it difficult to imagine that it was once the verdant Eden discovered by François Leguat and his companions when they arrived on the island at the end of the $17^{\text {th }}$ century; or that it could ever have been "the breadbasket of Mauritius." (Chaudenson et al. 1985). And yet the landscape nonetheless bears witness to Rodrigues' more glorious past, if only through the abandoned agricultural terraces, traces of which are still perceptible here and there on the hillsides (Figure 3); the surviving market gardens, deep in the humid valleys; and its domestic gardens. That heritage is also evidenced by the continued existence of herds of cows, goats and sheep that roam across improvised pasturelands.

Agriculture has indisputably left its mark on the landscape by supporting the local economy, shaping spatial occupancy, forming mindsets and codifying social organisation (Jauze 1998). So much so, in fact, that the current executive council, looking

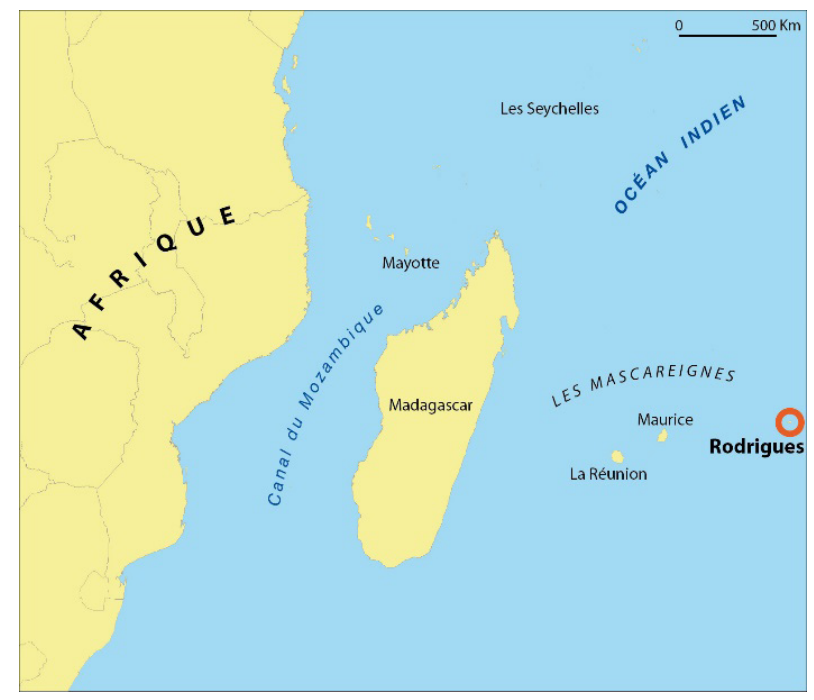

Figure 1. Rodrigues, located at a distance from its sister islands within the Mascarene archipelago (J.M. Jauze)

to tradition and rurality as exceptions within an archipelago that is opening up to modernity, is banking on an ecotourism-based policy as a means of strengthening the island's economy and attaining sustainability. Thus the countryside, which is both a social product and a cultural landmark, has become a focal point 
that is central to identity-related issues as well as economic and ecological ones. This new perspective on the landscape in the context of advanced deterioration is the guiding theme of this paper, and takes as its starting point the following question: How has rurality in Rodrigues given rise to a process of heritage value enhancement with the potential for ecotourism? Addressing this question requires, firstly, that we take a look back at Rodrigues as it was during the 'happy era' when it was a bountiful foodproducing land of fertile gardens. Then it entails an analysis of the transformations effected upon the island's landscape, and a particular focus on elements that have stood the test of time, so as to gain a clearer insight into the ways in which an ecotourismoriented approach has enhanced that heritage.

Rodrigues: a "watering place" and the "breadbasket of Mauritius"

When François Leguat and his companions approached the island in 1690 , the landscape that met their gaze was that of an earthly paradise. It was a landscape that Julian Hume, an English palaeontologist and artist, has tried to capture in his work (Figure 2), using the accounts provided by the island's first inhabitants, who described it thus:

"Here, tall, straight trees grow all around (...) Their huge, bushy tops almost all reach the same height, joining together to create a ceiling of permanent greenery, borne aloft by the natural pillars that bear and nourish them. This architecture is assuredly divine in nature. On this island, there is so great an abundance of tortoises that one can sometimes see herds of two or three thousand, and one can then walk over a hundred paces on their backs or, more accurately, on their shells, without setting foot on the ground." (Racault \& Carile 1995).

This image of the island as an earthly paradise, a land of plenty where anything grew and life was easy, is also described by accounts from the period, such as this excerpt from a letter written some time between 1795 and 1848:

"This year, experience has shown us that in the hills wheat yields are 5 to 1 ; an acre of land gives $200 \mathrm{~kg}$ of corn; ten to twelve pounds of rice have yielded around five hundred pounds. (...) Vegetables of all varieties grow well there. (...) We have several fruit trees: oranges, yellow and red lemons, limes, mangos, sugar apples, strawberry guavas, rose apples, bananas, pineapples, tamarinds, coconuts, dates..." (Berthelot 2002).

The following extract from an account by the authoress Lady Barker, who visited the island in the early $20^{\text {th }}$ century, reveals the presence, even then, of domestic gardens:

"Seated in her sedan chair, she travelled up along goat tracks, above enormous boulders, towards Saint Gabriel, and saw pretty, clean houses, each with its own vegetable garden where yams and sweet potatoes grew. (...) There were no signs of famine or hard times: everyone appeared plump, stout and contented; the babies were as chubby as thrushes and as merry as larks." (Berthelot 2002).

As well as serving as a watering place for passing sea vessels, the island also acted as the "breadbasket of Mauritius" as part of a colonial production plan. Since the arable land on Mauritius had been mostly given over to cash crops (coffee, tea, sugarcane), Rodrigues-where the lack of land and the hilly terrain made a plantation-style economy impossible-was to be a supply base for fruit, vegetables and meat (hence the expression

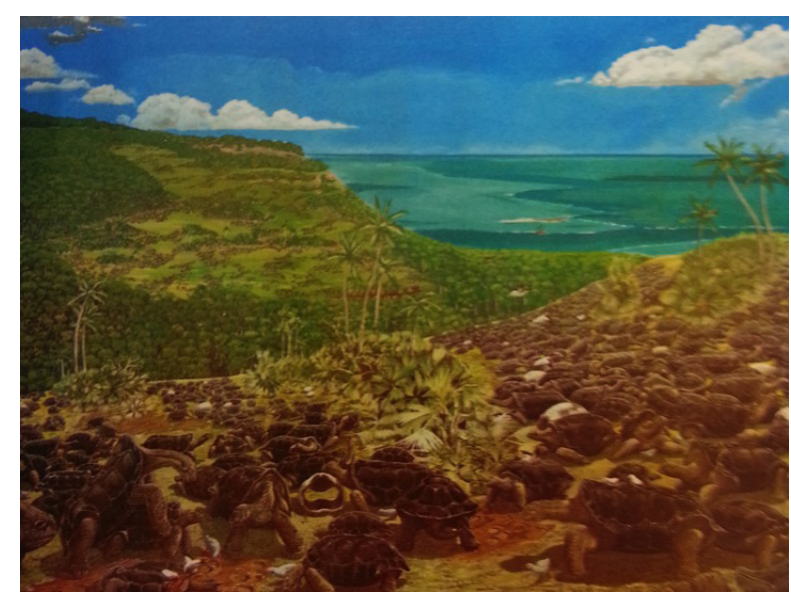

Figure 2. François Leguat's Eden, painted by Julian Hume (François Leguat Reserve Museum Photo J.M. Jauze)

"Cinderella of the Mascarenes"). The landscape of Rodrigues was markedly altered by its designated role as caterer to Mauritius since techniques and growing methods were adapted to suit the morphology of the land and the climate. It was at this time that the hillsides, cleared of their original vegetation, were beginning to be covered with verdant terraces, upon which corn, fruit and vegetable crops were grown.

As well as supplying Mauritius, Rodrigues, due to its remoteness from maritime routes crossing the Indian Ocean, also had to feed its own population. Alongside what one might describe as export-oriented agriculture, self-subsistence farming also developed, primarily in the form of domestic gardens, smallscale domestic farms which were characteristic of the way the islanders lived on and occupied their plots of land.

Domestic gardens and terraces were the two recurrent elements of this 'happy era' of food production, as described by the authors who have studied it (Dupon 1967, North-Coombes 1971, Chaudenson et al. 1985, Jauze 1998). It should be noted, incidentally, that this prosperous period also left its mark on local place names such as la Ferme (The Farm), le Chou (The Cabbage), Baie Citron (Lemon Bay), Pointe Mangues (Mango Point), Pointe Manioc (Manioc Point), Pointe Pistache (Peanut Point) and Pointe Coton (Cotton Point).

\section{Changes to landscape}

And yet that lush, verdant landscape was replaced by the dull, arid savannah that covers Rodrigues today, with the rock left bare in places (Figure 3). The description Le Clézio provides of the countryside in his novel Voyage to Rodrigues (Voyage à Rodrigues) differs markedly from Leguat's paradisiac vision: "Slack water, scorched stones, rotting schist, thorn bushes barring one's way: the ravine resembled the gateway to Hades. (...) A landscape of black stone, where the light is painful and the wind burns. A landscape of eternal refusal." (Le Clézio 1986). While this rather romanticized description is evidently a result of the author's desire to imbue his account with a specific atmosphere, the portrait he paints is nonetheless rooted in reality, in a landscape which has undergone significant change and indeed degradation that is directly ascribable to human recklessness (Simon 2009). As $95 \%$ of the land belonged first to the British crown and then to the state of Mauritius, both of whom were extremely lax in regard to the management of their territory, the inhabitants felt free to occupy it as they liked. Massive deforestation was carried out for agricultural requirements (slash and burn method): 
These Maroons continue their devastation and their fires throughout the island, creating widespread desolation. The fire caught easily due to the drought we have experienced this year, and it burned for over a month, destroying one of the finest areas of the island. (Berthelot 2002).

Wood was also required for kindling and construction, while the free pasturing of animals, particularly herds of goats, contributed significantly to the destruction of plant cover and in this way modified the natural water cycle. This anthropic factor was compounded by a purely physical one: due to its low-lying relief (culminating at 393m, on Mont Limon), the island does not "snag" clouds. These two causes also contribute to the chronic drought which affects Rodrigues.

These phenomena have combined to scar the landscape entirely. Due to problems with the farming economy the terraces were abandoned and the stones which had been used in their supporting walls were removed to construct roads or buildings. With each rainfall, particularly during the cyclone season between October and March, the terraces were gradually flattened and their thin upper layer of arable soil systematically washed down towards the sea causing significant damage to the lagoon. Nothing now grows on their surface apart from a meagre covering of grasses. In the most advanced stages of the process, when the terraces have been entirely flattened, the hillsides become eroded with the formation of wide, deep furrows.

The terraces were, in fact, abandoned in three stages. The first involved a form of rotation between crop cultivation and fallowed land over a period of one to two years. This was in an attempt to restore the fertility of the flat zones, if only partially, by using animal manure, and planting corn or manioc, which require less soil than fruit or vegetables. In the second stage, the land, now too poor and unsuitable for crop growth, was used as free grazing for animals. Finally, in the third stage, even the grassy cover struggled to grow due to water shortages and erosion set in: a truly ironic twist of fate for an island that suffers from lack of water.

Given the way the landscape has been transformed, at times alarmingly, one might well wonder whether anything iconic remains at all of Rodrigues.

\section{Gardens and landscapes facing the test of time}

Fortunately, the terraces have not all vanished. In some areas they have not only withstood the test of time but have in fact become a focus of renewed interest, boosted by new perspectives that have opened up in agriculture, particularly in relation to issues linked with ecotourism. Issues such as the drive to supply fresh local produce to homes and other accommodation, as well the push to conserve authentic, traditional activities. The Grande Montagne area in the centre of the island is a fine example of the perennial nature of such activities and landscapes, and has terraces where corn and onions are still grown (Figure 4).

Another example of how traditional agricultural practices have survived is to be found in the domestic gardens on the island (Figure 5). On plots of between 400 and 1,000 square metres, corn, fruit and vegetables are grown and domestic livestock is usually raised alongside, with the dual aim of ensuring on-thehoof savings and obtaining manure with which to fertilise the gardens.

These landscapes comprise four elements: the house, located on the edge of the plot, built gradually as income permits, with steel rods poking from the roof indicating plans for a possible upper floor; the garden, laid out neatly alongside; the concrete rainwater tank, to supplement irregular rainfall and finally, in an outlying area, the small fallow zone, providing pasture for the domestic herd, which usually includes one or two head of cattle, a few of smaller livestock (goats, sheep or pigs) and poultry.

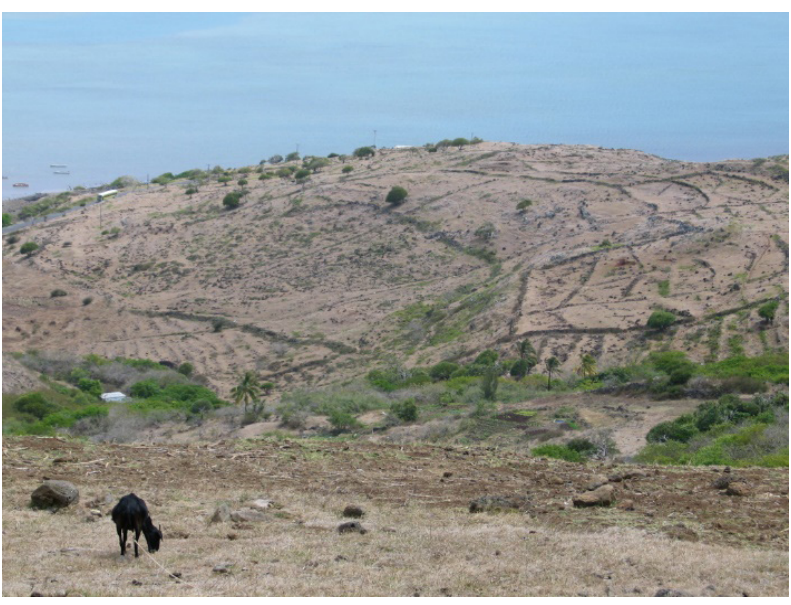

Figure 3. Modified landscape showing traces of former agricultural terraces (Photo J.M. Jauze)

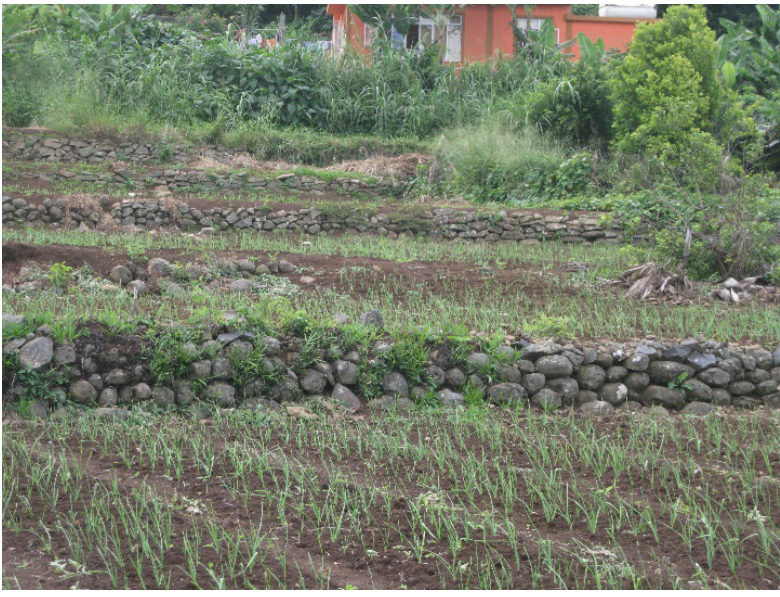

Figure 4. Onions growing on terraces in Grande Montagne (photo J.M. Jauze)

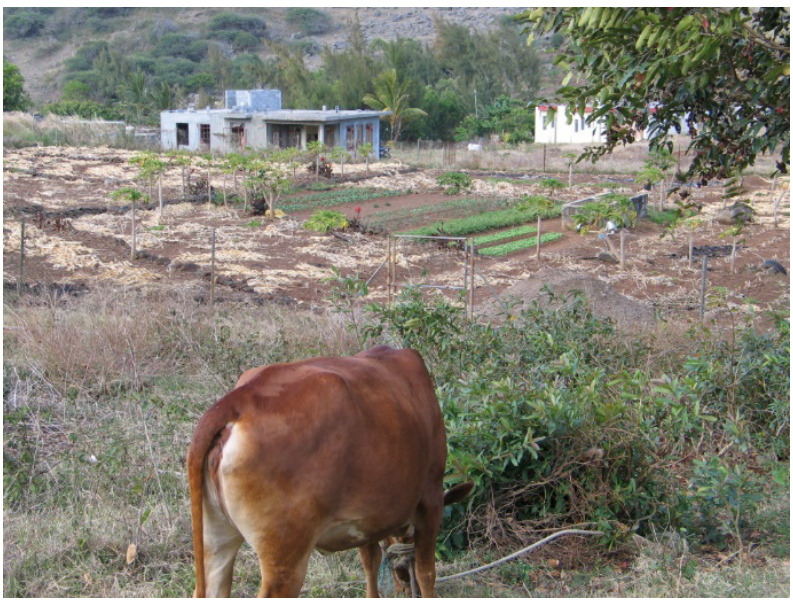

Figure 5. Typical landscape formed by a traditional domestic garden (photo J.M. Jauze)

On Rodrigues there is a garden landscape which has survived over the ages, valiantly braving the vagaries of climate and economic context. It nestles in low-lying, humid valleys such as Mourouck in the south-east or Anse Ally in the north- 
east. Although farming methods remain very traditional the flat land, fertile alluvial soils and permanent water supply allow for considerable yields and make these narrow valleys into little vegetable oases that stand out - in terms of production as well as colour - amidst the surrounding parched landscapes (Figure 3).

Finally, a traditional farming method has also stood the test of time. It was originally carried out using slash and burn techniques and then, when those were outlawed, by manually clearing parts of the forest. This age-old method gives visitors a glimpse of how disorderly plots once were, containing a mixture of all sorts of plants - manioc, corn and sweet potatoes - in an indescribable muddle. It relied upon the variations in plant growth cycles to ensure year-round production. Metal barrels for collecting rainwater are set amidst the crops, providing supplies for hand watering. These plots, which are generally only sketchily demarcated, contain remnants of forest growth and form a changing, blurred landscape, an essential characteristic of farming methods found in developing countries.

\section{Making the most of the island's heritage}

The authorities are aware of the problems facing the island and are attempting to protect its few remaining assets. They are looking to the tourist economy as a means of development, but are not considering just any form of tourism and have indeed shown a clear refusal to encourage mass tourism, which would merely exacerbate the situation, particularly in regard to the exploitation of resources on the island (Gay 1998). They have instead turned to ecotourism, which offers more protection for the natural environment and the local population.

To accomplish their aims they are not above bending the truth somewhat for marketing purposes, using slogans such as "Rodrigues, an untouched Paradise" ('lle Rodrigues, Paradis intouché ', Figure 6). The description can hardly fail to raise a smile from anyone aware of man's disastrous impact on the island. In fact, the authorities' approach is more akin to a "quest for lost Paradise" and, therefore, a desire to use ecotourism as a means of preserving what still remains.

Not only are the authorities trying to conserve existing resources, they are also emphasising traditional agricultural activities that reflect an image of Rodrigues as a peaceful island where life is good, with a timeless quality that sets it apart from the hubbub of modernity. In Saint-François, for instance, zones where agriculture had all but vanished have been regenerated in parallel with the development of guest house or gîte style accommodation that is totally immersed in rurality.

With a view to trying to return to the 'lost Paradise' that once existed on Rodrigues, attempts are being made to safeguard emblematic aspects of the island. In this respect, the presence of turtles is important in terms both of symbolism and heritage. To this end, a turtle reserve has been set up at Grande Caverne. It is called the "François Leguat Turtle Reserve" and offers guided tours that allow visitors to discover various species of turtle, as well as the limestone caves of the south-east (Figure 7). The aim is both educational and emotional. Above all, the point of the reserve is to educate visitors while simultaneously producing a specific emotional reaction: in this case reality is used to encourage visitors to imagine the virgin identity of the island before it was visited and inhabited by humankind.

Another attempt to recreate the emblematic heritage of Rodrigues is visible at the Five Senses Botanical Garden where an enjoyable educational trail allows visitors, using their five senses, to discover various different botanic species, including some endemic ones.

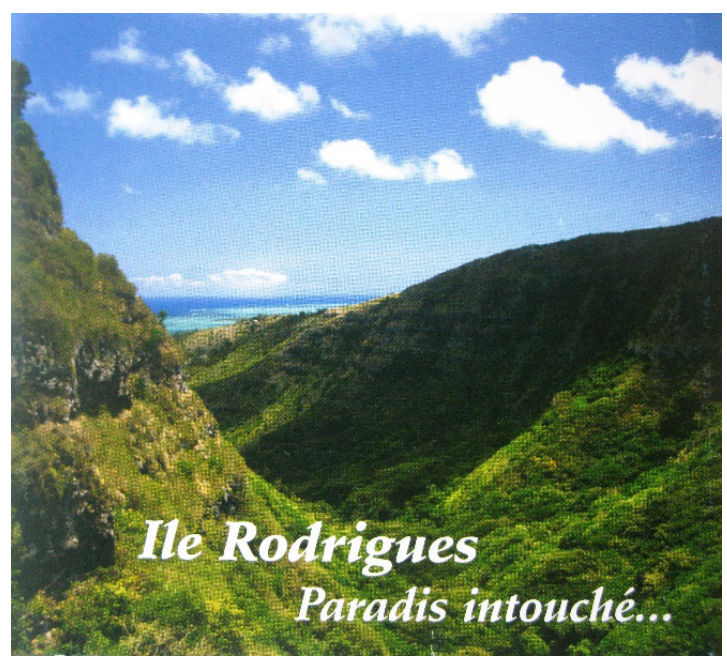

Figure 6. A catchy slogan, part of an ecotourist-oriented approach (Rodrigues Tourism Office)

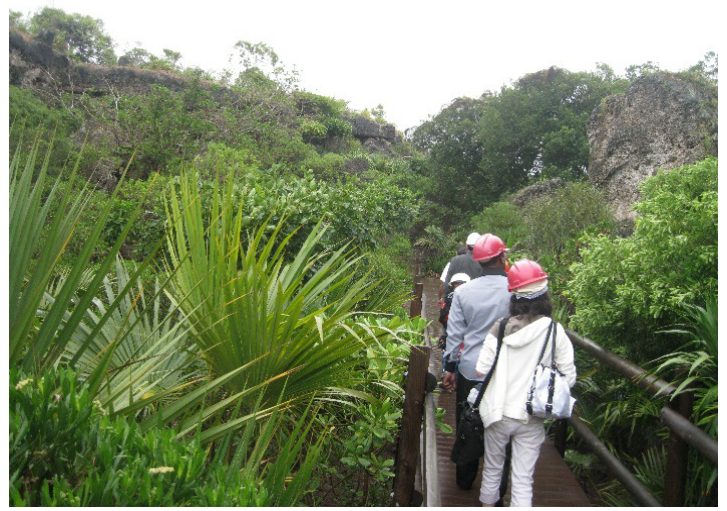

Figure 7. At the François Leguat Reserve: rediscovering the island's original state (photo J.M. Jauze)

The Montagne Malgache Zip Line is another agreeable, sports-oriented means of enjoying the beauty of the residual forest cover and the topography of the island.

These attractions, varyingly successful, all clearly emphasise the environmental potential of Rodrigues, and focus on heritage and attempt to enhance it while also preserving it.

\section{Conclusion}

On Rodrigues, as with most islands that remained isolated for a long period of time before opening up to the outside world, the process gradually transformed ways of life and landscapes. However, this particular island has an asset insofar as this opening-up occurred relatively recently, with the result that some authentic characteristics have remained intact such as the market gardens and a bucolic landscapes.

The island's authorities are now counting on this potential, within a touristic context that is constantly shifting within the region, to realise their ambitions: which is developing a nature-oriented form of tourism and working in proximity with the inhabitants, as expressed by the slogan "The Anti-stress Island." 
With this in mind, the ecotourism option holds promise as it contributes to further enhancement of the gardens and landscape, thereby attracting new interest in them on several levels:

- institutionally, through aid and re-creations,

- economically, by ensuring that agricultural produce is sold locally, and in terms of identity, through an emblematic form of acknowledgement and protection, which is a subject of ever increasing awareness and pride on the part of the population of Rodrigues.

\section{References}

Berthelot, L 2002, La Petite Mascareigne : aspects de l'histoire de Rodrigues, African cultural centre, Port Louis (Mauritius).

Chaudenson, R, Carayol, M \& Barat, C 1985, Rodrigues: la Cendrillon des Mascareignes. Institut de linguistique et d'anthropologie, University of Reunion Island.

Dupon, J-F 1967, 'L'île Rodrigues: experience de développement d'un milieu tropical dans l'archipel des Mascareignes', Annals of the Aix-en-Provence, Faculty of Arts, Aix-enProvence.

Gay, J-C 1998, 'La dynamique touristique de l'île Rodrigues (Maurice)', Actes des 7èmes Journées de géographie tropicale de Brest, Nantes, Ouest editions/Presses académiques, pp. 205212. Available from: <http://www. mgm.fr/ARECLUS/page_auteurs/Gay35.html>.
Jauze, J-M 1998, Rodrigues, la troisième île des Mascareignes, L'Harmattan, Paris.

Le Clézio, J-MG 1968, Voyage à Rodrigues, journal. NRF, Gallimard, Paris.

North-Combes, A 1971, The Island of Rodrigues, Mauritius Advertising Bureau, Port-Louis (Mauritius).

Racault, J-M \& Carile, P 1995, Voyage et aventure de François Leguat et de ses compagnons en deux îles désertes des Indes orientales (1690-1698), Les Editions de Paris, Paris.

Simon, T 2009, 'Rodrigues par les textes : paysage(s) écrits et perçus', Les Cahiers d'Outre-Mer, vol. 245, pp. 95109. Available from: <http://com.revues.org/5540, DOI: 10.4000/ com.5540> 